\section{Trial of levodopa in senile dementia}

Concentrations of various neurotransmitter enzymes in the brain may be reduced in patients suffering from Alzheimer's disease or senile dementia. ${ }^{12}$ Levodopa may alleviate the dopamine deficiency in the striatum in Parkinsonism, but there have been conflicting reports about its effect on any associated dementia. ${ }^{3}$ The drug has also been reported to improve the intellectual function of some patients suffering from senile dementia associated with extrapyramidal features. ${ }^{3}$ We have further assessed the effect of levodopa on senile dementia.

\section{Patients, methods, and results}

The patients studied were all women inpatients diagnosed as suffering from senile dementia, whose mean age was 78.9 years. None had serious extrapyramidal disease, and patients with severe heart disease, glaucoma liver disease, or peptic ulcer were excluded. The study was a double-blind crossover trial, patients receiving four weeks' treatment with placebo and four weeks' treatment with the active drug. The starting dose was $125 \mathrm{mg}$ daily, which was increased over two weeks to $875 \mathrm{mg}$ daily. None of the patients were receiving phenothiazines, haloperidol, antidepressants, antihypertensive agents, or sympathomimetic drugs. The Crichton Geriatric Behaviour Rating Scale was used at regular intervals by the same ward nursing staff, and the Crichton Intellectual Rating Scale ${ }^{4}$ was used by one member of the medical staff; the ratings were made blind at the end of weeks $0,2,4,6$, and 8 . A checklist of side effects was also completed.

Sixteen patients started the trial but two were withdrawn, one because of cholecystitis that developed during the placebo period and one because of a fractured femur that occurred during levodopa treatment, though there was no clear association with the drug. Fourteen patients completed the trial, and no other serious side effects were reported, although one patient became more irritable while taking the active preparation. Analysis of variance was used to test the significance of differences between mean scores in patients during the drug and placebo periods (see table). The results indicated a significant improvement in intellectual function during the drug phase; there was no significant change in any other area of behaviour with the exception of continence. Indices assessed by the intellectual rating scale and the communication part of the behaviour rating scale were broadly similar.

Significance of differences in mean scores between patients receiving placebo and patients receiving levodopa

\begin{tabular}{|c|c|c|c|c|}
\hline & & \multicolumn{2}{|c|}{ Mean scores } & \multirow{2}{*}{$\begin{array}{l}\text { Significance } \\
\text { (F ratio) }\end{array}$} \\
\hline & & Placebo & Levodopa & \\
\hline 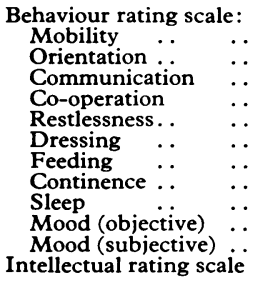 & 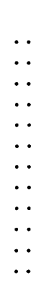 & $\begin{array}{l}4 \cdot 6 \\
2 \cdot 0 \\
2 \cdot 5 \\
3 \cdot 0 \\
4 \cdot 0 \\
2 \cdot 2 \\
3 \cdot 9 \\
3 \cdot 4 \\
4 \cdot 0 \\
3 \cdot 6 \\
3 \cdot 8 \\
2 \cdot 3\end{array}$ & $\begin{array}{l}4 \cdot 5 \\
2 \cdot 1 \\
3 \cdot 2 \\
3 \cdot 3 \\
4 \cdot 1 \\
2 \cdot 3 \\
3 \cdot 8 \\
3 \cdot 8 \\
4 \cdot 1 \\
3 \cdot 9 \\
3 \cdot 8 \\
3 \cdot 7\end{array}$ & $\begin{array}{l}\text { NS } \\
\text { NS } \\
\text { P }<0.001 \\
\text { NS } \\
\text { NS } \\
\text { NS } \\
\text { NS } \\
\text { P }<0.001 \\
\text { NS } \\
\text { NS } \\
\text { NS } \\
P<0.005\end{array}$ \\
\hline
\end{tabular}

NS $=$ Not significant

\section{Comment}

Our patients apparently made a significant improvement in intellectual function during treatment with levodopa. The findings must be treated with caution, however, as few patients were studied and the improvement might not be prolonged. Van Woert et al described the hazards of using higher doses of levodopa in this condition. ${ }^{5}$ The change in intellectual function was quite striking in some patients, and 10 of the 14 showed a clear improvement on the intellectual rating scale. In the absence of any change in most of the behavioural indices, however, intellectual improvements may be of only limited benefit.

We cannot explain this apparent intellectual improvement, and recently emphasis has been on a selective loss of central cholinergic neurones in Alzheimer's disease. Nevertheless, any agent that may produce benefit in this virtually untreatable condition is of interest and worthy of further investigation.

We are grateful to Roche Products Ltd for advice and for supplying the tablets used; Dr N Wallace and Dr M Peet for preliminary studies; and Sister A Ramsay, drug monitoring unit, Miss A Millar, pharmacist, and members of ward nursing staff for their help.

${ }^{1}$ Bowen, D M, et al, Lancet, 1974, 1, 1247.

2 White, P, et al, Lancet, 1977, 1, 668 .

3 Drachman, D A, and Stahl, S, Lancet, 1975, 1, 809.

${ }^{4}$ Robinson, R A, in Assessment in Cerebrovascular Insufficiency, ed G Stocker et al. Stuttgart, Georg Thieme Verlag, 1971.

5 Van Woert, M H, et al, Lancet, 1970, 1, 573.

(Accepted 25 October 1977)

Royal Dundee Liff Hospital, Dundee DD2 5NF

CHRISTOPHER LEWIS, MB, BSC, registrar

BRIAN R BALLINGER, MRCP, MRCPSYCH, consultant psychiatrist

ALLAN S PRESLY, PHD, DIP PSYCHOL, principal psychologist

\section{Benign intracranial hypertension in a child with eczema treated with topical steroids}

Benign intracranial hypertension is a rare complication of withdrawing steroid treatment, ${ }^{1}$ normally steroids taken by mouth. Only a few reports relate to its occurrence on withdrawal of topical steroids. ${ }^{2}{ }^{3}$ In our patient in whom benign intracranial hypertension was diagnosed, a boy with severe eczema having long-term topical steroid treatment, the decline of steroid absorption was almost certainly due to changes in his skin condition and to the instability of the steroid preparation used.

\section{Case report}

A 7-year-old boy with severe long-standing eczema was seen in the casualty department with a ten-day history of intense misery and headache, and a squint. His eczema (which covered his face, trunk, and limbs), although still severe, had improved over the preceding weeks. There had been no change in the skin treatment before he attended the casualty department. This treatment consisted of the daily application of $1 \%$ hydrocortisone in emulsifying ointment to the dry eczematous areas on his trunk and limbs, and daily baths with emulsifying ointment. The ointment was applied sparingly to the skin, and less than $10 \mathrm{~g}$ of the preparation were used a day. This treatment had been given for three years with regular repeat prescriptions from the hospital and the general practitioner.

Examination, apart from confirming his misery, showed bilateral papilloedema with an acuity of $6 / 12$ in the left eye; with the right he was only able to count fingers. There was a left lateral rectus palsy. His weight was on the 75 th and his height on the 25 th percentile, and his blood pressure was $90 / 65 \mathrm{~mm} \mathrm{Hg}$. Skull radiography and computerised axial tomography gave normal results.

The boy was treated initially with $4 \mathrm{mg}$ followed by $2 \mathrm{mg}$ six-hourly of parenteral dexamethasone, and then $15 \mathrm{mg}$ six-hourly of prednisone taken by mouth, which over several weeks was very slowly reduced. Headaches rapidly disappeared, the rectus palsy resolved within a week, his vision returned to normal, and the papilloedema resolved in about two weeks.

Analysis of the steroid content of the application being used on this patient showed that the hydrocortisone concentration had fallen in one container to $0 \cdot 19 \% \mathrm{w} / \mathrm{w}$, and in the other to $0 \cdot 16 \% \mathrm{w} / \mathrm{w}$. The contents of the containers when analysed were about four months old.

\section{Comment}

After our experience with this boy we are concerned that many more patients on topical steroid treatment are at risk of this 
complication. Absorption of any drug through the skin depends on several factors, including the state of the skin ${ }^{4}$-normal skin absorbing less of the topically applied drug than actively eczematous skin.

We are concerned also that the instability of some steroid preparations may cause them to deteriorate, so that the "dose" being given to the patient is lowered. The results of this could be disastrous. The British National Formulary obligation for expiry dates of two weeks applies to diluted creams but not to ointments. Nevertheless, it has been this hospital's practice over the past two years to list expiry dates even on diluted ointments. Patients with long-standing conditions do not like to bother their doctors for frequent repeat prescriptions and understandably like a supply to last some time. This is usually a sensible arrangement as long as the preparations are stable for a known period.

As a result of this case we think that the possibility of the complications of benign intracranial hypertension, although obviously uncommon, should not be forgotten in any patient on topical steroid treatment.

We are grateful to Dr John Wilson and Dr R S Wells for their advice and permission to report on a patient under their care and to the laboratory of the Government Chemist for performing the assay of the steroid preparation used in our patient.

${ }^{1}$ Neville, B G R, and Wilson, J, British Medical fournal, 1970, 3, 554.

2 Benson, R F, and Pharoah, P O D, Guy's Hospital Reports, 1960, 109, 212.

${ }^{3}$ Roussounis, S H, British Medical Fournal, 1976, 2, 564.

${ }^{4}$ Munro, D D, British fournal of Dermatology, 1976, 94, suppl 12, 67.

(Accepted 10 November 1977)

Hospital for Sick Children, Great Ormond Street, London WC1

GWILYM P HOSKING, MRCP, DCH, neurological registrar (present appointment: consultant in paediatric neurology, The Ryegate Centre, (The Children's Hospital), Sheffield S10 5DD)

HEATHER ELLISTON, MPS, group chief pharmacist

\section{Lead-induced hypertension: blunted beta-adrenoceptor-mediated functions}

Hypertension is one of the possible sequelae of lead poisoning. ${ }^{1} \mathrm{We}$ describe here a case of severe lead poisoning with hypertension in which data on plasma catecholamines, the renin-angiotensin-aldosterone system, and beta-adrenoceptor sensitivity pointed to reduced beta-adrenoceptor responses similar to those observed in low-renin essential hypertension.

\section{Case report}

After cleaning his garage, which had once been a lead foundry, a healthy, normotensive 65-year-old man (a regular blood donor) developed pronounced lead poisoning as a result of inhaling lead dust. He at first complained of loss of appetite, intestinal spasms, and reduced capacity for exertion. Six weeks later the lead concentrations in his blood and urine were $12.46 \mu \mathrm{mol} / \mathrm{l}(258 \mu \mathrm{g} / 100 \mathrm{ml})$ and $38.64 \mu \mathrm{mol} / 1(800 \mu \mathrm{g} / 100 \mathrm{ml})$-four to five times the acceptable upper limit. He had typical lead anaemia (haemoglobin $7.0 \mathrm{~g} / \mathrm{dl}$ ), with an increase in $\delta$-aminolaevulinic acid in plasma $(1.31 \mathrm{mmol} / \mathrm{l}(17.18 \mathrm{mg} / 100 \mathrm{ml}))$ and urine $(1.45 \mathrm{mmol}(190.15 \mathrm{mg}) / 24 \mathrm{~h})$ -a usual result of inhibition of haem synthesis. In view of his temporarily reduced renal function (serum creatinine maximum concentration 150 $\mu \mathrm{mol} / 1(1.7 \mathrm{mg} / 100 \mathrm{ml}))$, we did not treat the lead poisoning with edetic acid. His blood pressure rose to $160-170 / 100-105 \mathrm{~mm} \mathrm{Hg}$.

After twelve months the patient's blood pressure in the supine position was still $140-170 / 95-105 \mathrm{~mm} \mathrm{Hg}$. Plasma renin activity was suppressed to $352 \mathrm{pmol} / \mathrm{l} / \mathrm{h}(271 \mathrm{pg} / \mathrm{ml} / \mathrm{h}$ ) after salt depletion (urinary sodium excretion $37 \mathrm{mmol}(\mathrm{mEq}) / 24 \mathrm{~h})$. After he had had a 30-minute rest lying down we determined the dose-response curve for isoprenaline hydrochloride and found the chronotropic dose $25{\left(C^{2}\right.}_{25}$, the dose required to increase heart rate by 25 beats $/ \mathrm{min}) .^{2}$ Subsequently we investigated the patient before and during gradually increasing bicycle ergometric exercise up to $100 \mathrm{~W}$ in a sitting position (table). His maximal physical work capacity $\left(\mathrm{PWC}_{\max }\right.$ ) was then $150 \mathrm{~W}$.

\section{Discussion}

Lead poisoning appears to have been responsible for the rapid development of hypertension and the other abnormalities in our patient. The plasma noradrenaline concentrations were higher than in five normal controls; but his beta-adrenoceptor-mediated functions -for example, maximal heart rate, renin release, and isoprenalineinduced tachycardia - were blunted.

Lead binds reactive anions such as sulphur and phosphorus and thus affects enzymes associated with membranes. Consequently, it impairs the synthesis of haem and that of sodium-potassiumactivated adenosinetriphosphatase, ${ }^{3}$ and probably also interferes with the receptor-adenylate cyclase system. This would reduce beta-adrenoceptor-mediated vasodilatation as well as exercise tachycardia and renin release. On this hypothesis, reactive sympathoneural activity-reflected in the raised plasma noradrenaline-would cause alpha-adrenoceptor-mediated vasoconstriction and contribute to the rise in blood pressure.

Biochemical abnormalities similar to those induced by lead may be found in elderly subjects, especially those with essential hypertension. They too show a disturbance of the normal balance, with raised plasma noradrenaline concentrations ${ }^{4}$ and hyporesponsive beta-adrenoceptor functions-for example, renin activity, exercise tachycardia, ${ }^{5}$ and isoprenaline sensitivity. In patients with low-renin essential hypertension, adaptive changes of the receptor-effector complex may result from chronic sympathoneural hyperactivity or the usually prolonged hypertension, or both.

1 Lane, E R, British fournal of Industrial Medicine, 1949, 6, 125

${ }^{2}$ Cleaveland, C R, Rangno, R E, and Shand, D G, Archives of Internal Medicine, 1972, 130, 47.

${ }^{3}$ Hansan, J, Vihko, V, and Hernberg, S, Archives of Environmental Health, $1967,14,313$.

${ }^{4}$ Lake, C R, et al, New England fournal of Medicine, 1977, 296, 208.

5 Bühler, F R, et al, American fournal of Cardiology, 1975, 36, 653.

(Accepted 9 November 1977)

Department of Medicine, University of Basel, Kantonsspital Basel, 4031 Basel, Switzerland

O BERTEL, MD, research fellow

F R BÜHLER, MD, head of hypertension unit

J OTT, MD, general practitioner

High plasma noradrenaline concentration, low plasma renin activity, and low isoprenaline sensitivity in lead-induced hypertension: blunted response of beta-adrenoceptormediated functions to stimulation at rest and during ergometry. Values are means $\pm S D$

\begin{tabular}{|c|c|c|c|c|}
\hline & \multicolumn{2}{|c|}{ Patient with lead-induced hypertension } & \multicolumn{2}{|c|}{ Five controls } \\
\hline & Supine & $\begin{array}{c}\text { Exercise at } \\
100 \text { Watt }\end{array}$ & Supine & $\begin{array}{l}\text { Exercise at } \\
100 \text { Watt }\end{array}$ \\
\hline $\begin{array}{l}\text { Plasma noradrenaline (nmol/l) } \\
\text { Plasma adrenaline (nmol/1) } \\
\text { Plasma dopamine (nmol/l) } \\
\text { Plasma renin activity (pmol/l/h) } \\
\text { Blood pressure systolic (mm Hg) } \\
\text { Blood pressure diastolic }(\mathrm{mm} \mathrm{Hg}) \\
\text { Heart rate (beats/min) } \\
\text { Heart rate at PWC } \mathrm{PWax}(\mathrm{beats} / \mathrm{min}) \\
\mathrm{CD}_{25} \text { isoprenaline }\left(\mathrm{nmol} / \mathrm{m}^{2}\right)\end{array}$ & $\begin{array}{r}2 \cdot 21 \\
0 \cdot 43 \\
0 \cdot 84 \\
254 \\
152 \\
106 \\
62\end{array}$ & $\begin{array}{r}11 \cdot 35 \\
0 \cdot 88 \\
1 \cdot 42 \\
4 \cdot 86 \\
240 \\
118 \\
98\end{array}$ & $\begin{array}{c}1.57 \pm 0.30 \\
0 \cdot 34 \pm 0.61 \\
0 \cdot 72 \pm 0 \cdot 14 \\
2539 \pm 846 \\
142 \pm 4 \\
84 \pm 3 \\
71 \pm 2\end{array}$ & $\begin{array}{c}6.33 \pm 2.34 \\
0.83 \pm 0.18 \\
1.09 \pm 0.33 \\
4091 \pm 1340 \\
164 \pm 5 \\
94 \pm 4 \\
114 \pm 3\end{array}$ \\
\hline
\end{tabular}

